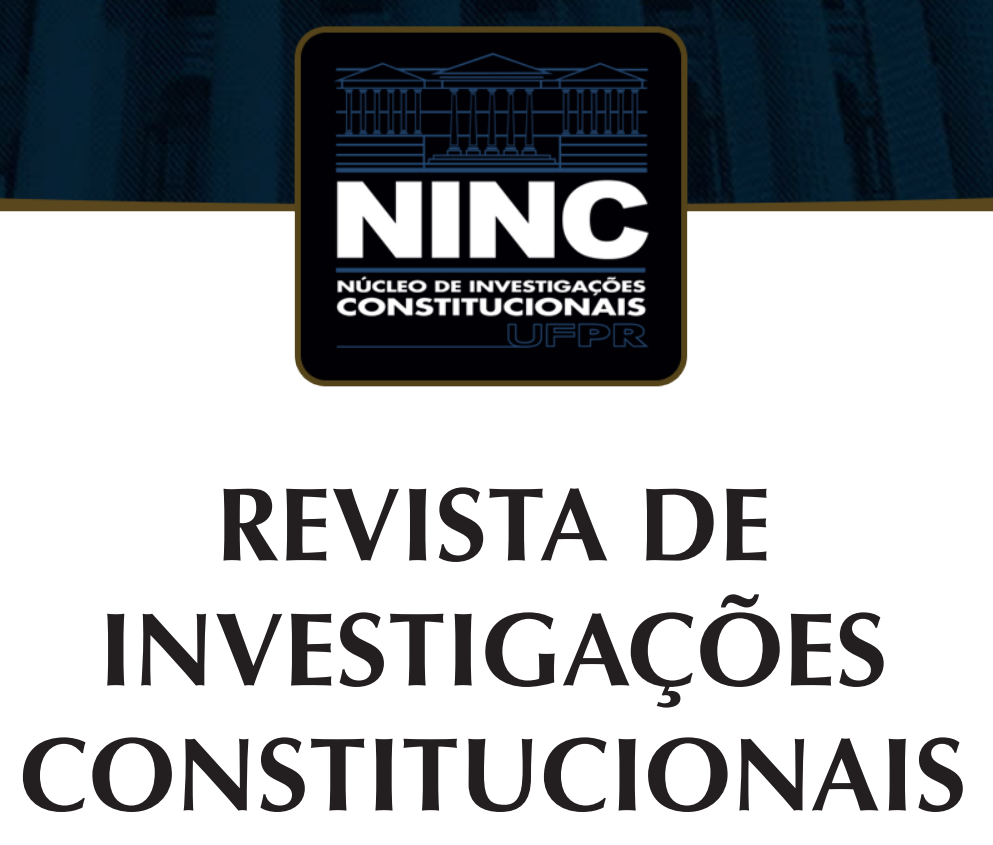

JOURNAL OF CONSTITUTIONAL RESEARCH

vol. 8 | n. 1 | janeiro/abril 2021 | ISSN 2359-5639 | Periodicidade quadrimestral Curitiba | Núcleo de Investigações Constitucionais da UFPR | www.ninc.com.br 


\title{
A superação das decisões do STF pelo Congresso Nacional via emendas constitucionais: diálogo forçado ou monólogos sobrepostos?
}

\section{The override of Brazilian Supreme Court's decisions by the National Congress through constitutional amendments: forced dialogue or overlapping monologues?}

\author{
DANIEL WUNDER HACHEM 1,11 , * \\ 'Pontifícia Universidade Católica do Paraná (Curitiba, Paraná, Brasil) \\ " Universidade Federal do Paraná (Curitiba, Paraná, Brasil) \\ danielhachem@gmail.com \\ http://orcid.org/0000-0001-8519-8420 \\ ELOI PETHECHUST III, ** \\ III FAE Centro Universitário (Curitiba, Paraná, Brasil) \\ pethechust@hotmail.com \\ http://orcid.org/0000-0003-1962-1539 \\ Recebido/Received: 30.03.2020 / March 30 32020 \\ Aprovado/Approved: 16.04 .2021 / April 16 ${ }^{\text {th }}, 2021$
}

\section{Resumo}

O sistema brasileiro de controle jurisdicional de constitucionalidade confere amplos poderes ao Supremo Tribunal Federal em matéria de definição do sentido da Constituição. Como reação a esse modelo forte de controle, o Congresso Nacional tem adotado como estratégia de reação a aprovação de emendas constitucionais como forma de superação das decisões judicial declaratórias de

\section{Abstract}

The Brazilian system of judicial review confers broad powers to the Federal Supreme Court regarding the definition of the meaning of the Constitution. As a reaction to this strong model of control, the National Congress has adopted as a reaction strategy the approval of constitutional amendments as a way of overriding judicial decisions that strike down legislation. The article aims to examine

Como citar esse artigo/How to cite this article: HACHEM, Daniel Wunder; PETHECHUST, Eloi. A superação das decisões do STF pelo Congresso Nacional via emendas constitucionais: diálogo forçado ou monólogos sobrepostos? Revista de Investigações Constitucionais, Curitiba, vol. 8, n. 1, p. 209-236, jan./abr. 2021. DOI: 10.5380/rinc.v8i1.82738.

" Professor da Graduação, Mestrado e Doutorado em Direito da Pontifícia Universidade Católica do Paraná e da Universidade Federal do Paraná (Curitiba-PR, Brasil). Pós-Doutorado pela Université Paris 1 Panthéon-Sorbonne. Doutor e Mestre em Direito do Estado pela Universidade Federal do Paraná. E_mail: danielhachem@gmail.com.

"* Professor da FAE Centro Universitário (Curitiba-PR, Brasil). Doutor em Direito pela Pontifícia Universidade Católica do Paraná Mestre em Direito pela Pontifícia Universidade Católica do Paraná. Especialista em Direito Processual Civil pelo Instituto Bacellar. E-mail: pethechust@hotmail.com. 
inconstitucionalidade. $\mathrm{O}$ artigo tem como objetivo examinar esse fenômeno tomando como base a teoria dos diálogos constitucionais desenvolvida no Direito canadense, utilizando como marco teórico as ideias de Peter Hogg e Allison Bushell, Kent Roach e Luc Tremblay, para verificar se é possível considerar essa interação entre Legislativo e Judiciário como um autêntico diálogo constitucional. O método utilizado foi a revisão bibliográfica, o estudo de casos e a análise de jurisprudência e das manifestações dos parlamentares no Congresso Nacional. O estudo conclui que em todos os cinco casos analisados não houve efetivo diálogo, mas sim uma sobreposição de monólogos entre os atores envolvidos, uma vez que as razões do Supremo Tribunal Federal em geral não são levadas em consideração pelo Congresso Nacional.

Palavras-chave: diálogos constitucionais; supremacia judicial; controle jurisdicional de constitucionalidade; democracia; emendas constitucionais. this phenomenon based on the theory of constitutional dialogues developed in Canadian law, using as theoretical framework the ideas of Peter Hogg and Allison Bushell, Kent Roach and Luc Tremblay, to verify if it is possible to consider this interaction between Legislative and Judiciary as an authentic constitutional dialogue. The method used was the bibliographical review, the case study, the analysis of jurisprudence and the manifestations of the parliamentarians in the National Congress. The study concludes that in all the five cases analyzed there was no effective dialogue, but rather an overlap of monologues among the actors involved, since the reasons of the Brazilian Federal Supreme Court in general are not taken into account by the National Congress.

Kaywords: constitutional dialogues; judicial supremacy; judicial review; democracy; constitutional amendments.

\section{SUMÁRIO}

1. Introdução; 2. Os diálogos constitucionais como alternativa aos problemas da supremacia judicial;

3. As emendas constitucionais como mecanismo utilizado pelo Congresso Nacional brasileiro para superar as decisões do Supremo Tribunal Federal; 4. Há diálogos entre Legislativo e Judiciário na experiência brasileira de emendas constitucionais que superam a jurisprudência? 5. Conclusão. 6. Referências.

\section{INTRODUÇÃO}

Desde a promulgação da Constituição de 1988, tem-se assistido no Brasil um processo de fortalecimento das atribuições do Poder Judiciário em geral e do Supremo Tribunal Federal em particular, notadamente em matéria de controle de constitucionalidade e de definição do significado da Constituição. O crescimento de mecanismos do controle abstrato e concentrado de constitucionalidade, desde a ampliação do rol de legitimados para propor Ação Direta de Inconstitucionalidade e Ação Declaratória de Constitucionalidade até a criação do instituto das Súmulas Vinculantes, tem conduzido à apreciação da Suprema Corte brasileira um conjunto relevante de questões políticas, cuja resolução ocasiona significativos impactos para a vida em sociedade.

Como reação a esse fenômeno, observa-se, de um lado, o desenvolvimento de teorias que buscam retirar o monopólio da interpretação da Constituição das mãos do Poder Judiciário, bem como subtrair-lhe o poder de dar a última palavra sobre o significado constitucional, como é o caso das teorias dos diálogos institucionais. De outro lado, verifica-se que o próprio Poder Legislativo brasileiro tem adotado medidas para superar normativamente o entendimento do STF em matéria constitucional, como é o caso da aprovação de emendas à Constituição que contrariam decisões judiciais declaratórias de inconstitucionalidade. 
Diante desse quadro, justifica-se a realização de uma investigação sobre as reações do Congresso Nacional às decisões do Supremo Tribunal Federal mediante a modificação do texto constitucional como forma de superação da compreensão da Corte. Afinal, tais práticas realizadas pelo Poder Legislativo brasileiro são admitidas pela Constituição da República? Estariam elas caracterizadas como autênticos diálogos constitucionais, nos termos da teoria contemporânea do Direito Constitucional, funcionando como um mecanismo legítimo de mudança do quadro de supremacia judicial vivenciado na experiência brasileira até então? A ocorrência de tais práticas legislativas que desafiam a atuação judicial reclama um estudo aprofundado acerca do assunto.

Sendo assim, o objetivo deste artigo consiste em analisar, dentro do cenário de fortalecimento do Poder Judiciário brasileiro no sistema de controle jurisdicional de constitucionalidade, se as mudanças da Constituição realizadas reativamente pelo Congresso Nacional com o intuito específico de superar normativamente as decisões de inconstitucionalidade do Supremo Tribunal Federal podem ou não ser consideradas como práticas dialógicas, nos termos da teoria dos diálogos institucionais desenvolvida no Direito canadense. Toma-se como marco teórico o pensamento de Peter Hogg e Allison Bushell, Kent Roach e Luc Tremblay.

A hipótese da qual se parte é que as interações entre o Poder Legislativo e o Poder Judiciário no Brasil em matéria de controle de constitucionalidade e aprovação de emendas à Constituição se caracteriza mais como uma sobreposição de monólogos, em que cada ator tenta fazer prevalecer sua posição sem grandes tentativas de incorporar as contribuições de seu interlocutor, do que propriamente como um autêntico diálogo institucional.

O método adotado para a investigação será a revisão bibliográfica e o estudo de casos que envolvem o objeto acima mencionado, mediante pesquisa de jurisprudência do STF e de manifestações das Comissões de Constituição e Justiça das casas do Congresso Nacional a respeito das propostas de emenda à Constituição examinadas. A metodologia da pesquisa se desenvolverá em três etapas: (i) utilização das teorias dos diálogos institucionais desenvolvidas por Peter Hogg e Allison Bushell, refinadas por Kent Roach e criticadas por Luc Tremblay, como parâmetro de verificação da possibilidade de enquadrar os casos brasileiros de emendas à Constituição que superam decisões do STF como formas genuínas de "diálogos institucionais"; (ii) seleção de cinco casos em que o Congresso Nacional nitidamente aprovou emendas para contrariar o posicionamento do Supremo Tribunal Federal; (iii) aplicação dos conceitos de diálogos institucionais utilizados por Hogg e Bushell, Roach e Tremblay como ferramenta para análise dos casos brasileiros.

Ao final, serão apresentadas as conclusões a que se chegou ao longo da investigação. Entre elas, destaca-se a constatação de que a prática de aprovação de emendas constitucionais para superar decisões de inconstitucionalidade do STF se configurou, 
na maioria das vezes, mais como uma sobreposição de monólogos entre o Congresso Nacional e a Corte, por se revelar como uma tentativa do Legislativo de fazer prevalecer as suas razões sobre a interpretação atribuída pelo Supremo Tribunal Federal, sem levar em conta as contribuições judiciais para o debate. Por outro lado, verificou-se também que as reações adotadas pelo Parlamento tiveram como aspecto positivo a retomada de temas relevantes de índole constitucional para a esfera de deliberação democrática, o que acabou sendo provocado pelas decisões de inconstitucionalidade proferidas pelo STF.

\section{OS DIÁLOGOS CONSTITUCIONAIS COMO ALTERNATIVA AOS PROBLEMAS DA SUPREMACIA JUDICIAL}

Nas últimas décadas, em distintas localidades do globo, tem se percebido um robustecimento do papel exercido por Supremas Cortes e Cortes Constitucionais em temas de forte coloração política, levando-as a decidir a respeito de políticas públicas e de temas que envolvem expressivo desacordo moral dentro da sociedade. Com isso, o Poder Judiciário passou, de forma institucional, a interferir diretamente no processo democrático. Tal tendência é batizada por Ran Hirschl de "juristocracia", compreendida como uma visão da democracia que reconhece a Cortes Supremas e Tribunais Constitucionais legitimidade para tomar decisões políticas de caráter contramajoritário, por meio da interpretação de catálogos de direitos fundamentais. O princípio da soberania do Parlamento, pautado na vontade da maioria eleita, deixa de ser o único elemento a caracterizar as democracias, passando a conviver com a prerrogativa dos juízes de conferir tutela jurídica aos direitos das minorias resguardados no texto constitucional. ${ }^{1}$

Contudo, apesar de a ingerência do Poder Judiciário na arena da política majoritária ter sido admitida em alguns Estados, ampliando-se a quantidade de atores sociais que recorrem aos juízes para resolver seus problemas individuais e os identificam como guardiões da ordem e do sistema jurídico, ${ }^{2}$ ela também sofre duras críticas decorrentes da inexistência (ou ineficácia) de instrumentos de responsabilidade e de controle da atividade judicial. ${ }^{3}$ Em determinados países, a assunção de novas atribuições pelo Poder Judiciário desvinculada da imposição de limites e não sujeita a controles tem

HIRSCHL, Ran. Towards juristocracy: the origins and consequences of the new constitutionalism. Cambridge: Harvard University Press, 2004. p. 1-2.

2 GARAPON, Antoine. O juiz e a democracia: o guardião de promessas. 2. ed. Rio de Janeiro: Revan, 2001. p. 55.

3 Outra ordem de críticas diz respeito à separação de poderes. Nesse sentido, ver: AVILA, Ana Paula Oliveira; MELO, Karen Cristina Correa de. Separação de poderes e diálogos institucionais nos litígios envolvendo o direito à saúde. Revista de Investigações Constitucionais, Curitiba, vol. 5, n. 1, p. 83-108, jan./abr. 2018; LIMA, Fernando Rister de Souza; VILLAS BÔAS FILHO, Orlando. Separação dos poderes e complexidade social - uma releitura sistêmica. Revista de Investigações Constitucionais, Curitiba, vol. 5, n. 1, p. 189-220, jan./abr. 2018. 
levado a abusos e à edificação de um superpoder, caracterizado por um forte ativismo, ${ }^{4}$ com ascendência sobre os demais poderes constituídos. ${ }^{5}$

É nesse sentido que surgem as críticas aos modelos que preconizam uma "supremacia judicial", ${ }^{6}$ nos quais se confere ao Poder Judiciário a prerrogativa de dar a última palavra a respeito da interpretação e atribuição de sentido ao conteúdo da Constituição. ' É o caso de ordenamentos jurídicos como o brasileiro, que outorgam amplos poderes aos órgãos jurisdicionais para o exercício do controle de constitucionalidade das leis e atos normativos, permitindo-lhes até mesmo declarar a nulidade de emendas à Constituição aprovadas pelo poder reformador, por extrapolarem limites materiais impostos aos processos formais de mudança das disposições constitucionais. ${ }^{8}$

Em face do déficit democrático de que padece o modelo forte de controle jurisdicional de constitucionalidade, notadamente no que toca à tomada de decisões sobre temas constitucionais sensíveis que envolvem fortes desacordos morais no âmbito da sociedade, ${ }^{9}$ as teorias dialógicas surgem como alternativa. ${ }^{10}$ Entre seus objetivos, encontra-se o propósito de equilibrar o caráter contramajoritário do Poder Judiciário (responsável por tutelar direitos constitucionais de minorias ameaçados por maiorias eventuais no Legislativo) com a questão democrática (que reclama a participação dos atores legitimados pelo voto popular no processo de atribuição de sentido à Constituição), ${ }^{11}$ além do escopo de construir um processo de deliberação que seja compatível com a complexidade dos temas constitucionais. ${ }^{12}$

\footnotetext{
4 Ver sobre o tema: ARAÚJO, Luiz Fernando Diniz. O ativismo judicial e constrangimentos a posteriori. Revista de Investigações Constitucionais, Curitiba, vol. 5, n. 1, p. 129-150, jan./abr. 2018.

5 CARVALHO FILHO, José dos Santos. Entre o guardião de promessas e o superego da sociedade: limites e possibilidades da jurisdição constitucional no Brasil. Revista de informação legislativa, v. 51, n . 202, p. 159179, abr./jun. 2014.

6 Uma das fortes críticas a esse modelo é desenvolvida pela corrente do constitucionalismo popular. Nesse sentido: VIEIRA, José Ribas; EMERIQUE, Lilian Márcia Balmant; BARREIRA, Jônatas Henriques. Constitucionalismo popular: modelos e críticas. Revista de Investigações Constitucionais, Curitiba, vol. 5, n. 3. p. 277-302, set./dez. 2018.
}

7 Nesse sentido, ver: BRANDÃO, Rodrigo. Supremacia judicial versus diálogos constitucionais: a quem cabe a última palavra sobre o sentido da Constituição? Rio de Janeiro: Lumen Juris, 2012.

8 SILVA, Virgílio Afonso da. O STF e o controle de constitucionalidade: deliberação, diálogo e razão pública. Revista de Direito Administrativo, Rio de Janeiro, v. 250, p. 197-227, jan./abr. 2009. p. 217-218.

9 BRANDÃO, Rodrigo. Supremacia judicial versus diálogos constitucionais: a quem cabe a última palavra sobre o sentido da Constituição? Rio de Janeiro: Lumen Juris, 2012. p. 187-189.

10 HACHEM, Daniel Wunder; PETHECHUST, Eloi. Supremacia judicial no constitucionalismo brasileiro: riscos à democracia e as alternativas das teorias dos diálogos constitucionais. Revista Brasileira de Estudos Políticos, v. 121, p. 203-250, jul./dez. 2020.

11 Ver: LIMA, Flávia Danielle Santiago; GOMES NETO, José Mário Wanderley. Autocontenção à brasileira? Uma taxonomia dos argumentos jurídicos (e estratégias políticas?) explicativo(a)s do comportamento do STF nas relações com os poderes majoritários. Revista de Investigações Constitucionais, Curitiba, vol. 5, n. 1, p. 221247, jan./abr. 2018.

12 SILVA, Cecília de Almeida; MOURA, Francisco; BERMAN, José Guilherme; VIEIRA, José Ribas; TAVARES, Rodrigo de Souza; VALLE, Vanice Regina Lírio do. Diálogos institucionais e ativismo. Curitiba: Juruá, 2010. p. 23-33. 
A premissa comum das teorias que giram em torno do conceito de "diálogos constitucionais" reside na ideia de que a interpretação da Constituição não deve se encerrar em um monopólio situado nas mãos do Poder Judiciário e das Cortes Constitucionais. ${ }^{13} \mathrm{O}$ significado da ordem constitucional deve resultar de um diálogo entre os tribunais e os demais atores institucionais. Portanto, em um sentido amplo, pode-se dizer que as "teorias dialógicas" remetem a uma interlocução entre os tribunais e as demais instituições políticas e sociais no que diz respeito à definição do sentido da Constituição. ${ }^{14}$

Este seria, pois, um dos traços mais marcantes dessa linha teórica: a recusa em atribuir-se o poder de dar a última palavra sobre a interpretação constitucional a uma única instituição, afastando-se tanto da noção de supremacia judicial, quanto da ideia de supremacia legislativa, para apostar em um processo compartilhado de construção do conteúdo semântico da Constituição. ${ }^{15}$ Existe uma ampla variedade de versões a respeito de como deve se dar essa interação e que ainda assim são, por alguns autores, reunidas sob a mesma expressão "teorias dos diálogos constitucionais". ${ }^{16}$

Por outro lado, há autores, como é caso de Rodrigo Brandão, ${ }^{17}$ que preferem reservar a locução "teoria dos diálogos constitucionais" para a corrente teórica desenvolvida no marco do Direito canadense a partir do artigo precursor de Peter Hogg e Allison Bushell, ${ }^{18}$ e seguida por autores como Kent Roach. ${ }^{19} \mathrm{Em}$ seu estudo pioneiro, Hogg e Bushell sustentam que o sistema de controle jurisdicional de constitucionalidade desenhado pela Carta Canadense de Direitos e Liberdades de 1982 não sofre de ilegitimidade democrática, pois, a partir de uma pesquisa empírica, demonstram que em quase todos os casos em que uma lei foi invalidada judicialmente, houve uma reação subsequente do Legislativo criando novas leis que atingiam os mesmos objetivos

13 BATEUP, Christine. The dialogic promise: assessing the normative potential of theories of constitutional dialogue. Brooklyn Law Review, New York, v. 71, n. 3, p. 1109-1180, 2006. p. 1109.

14 MANEIRO, Renata de Marins Jaber. Mandado de injunção, diálogos constitucionais e o papel do STF. Curitiba: Juruá, 2016. p. 64.

15 MANEIRO, Renata de Marins Jaber. Mandado de injunção, diálogos constitucionais e o papel do STF. Curitiba: Juruá, 2016. p. 66.

16 Nesse sentido: BATEUP, Christine. The dialogic promise: assessing the normative potential of theories of constitutional dialogue. Brooklyn Law Review, New York, v. 71, n. 3, p. 1109-1180, 2006. Na perspectiva brasileira, ver: BARBOSA, Antonio Ezequiel Inácio; LIMA, Martonio Mont'alverne Barreto. Influência das teorias dos diálogos institucionais e da última palavra provisória no pensamento constitucional brasileiro contemporâneo. Revista de Investigações Constitucionais, Curitiba, vol. 5, n. 1, p. 109-128, jan./abr. 2018.

17 BRANDÃO, Rodrigo. Supremacia judicial versus diálogos constitucionais: a quem cabe a última palavra sobre o sentido da Constituição? Rio de Janeiro: Lumen Juris, 2012. p. 273.

18 HOGG, Peter W.; BUSHELL, Allison A. The Charter dialogue between courts and legislatures (or perhaps the Charter of Rights isn't such a bad thing after all). The Osgoode Hall Law Journal, Toronto, v. 35, n. 1, p. 75-124, 1997.

19 ROACH, Kent. Constitutional and Common Law dialogues between the Supreme Court and Canadian legislatures. Canadian Bar Review, Ottawa, v. 80, n. 1-2, p. 481-533, mar./jun. 2001. 
daquelas que haviam sido anuladas. Os processos envolvendo questões de constitucionalidade das leis deveriam, pois, ser considerados como "diálogos" entre o Judiciário e o Legislativo, já que o controle judicial não operaria como um obstáculo às manifestações democráticas, mas sim como um deflagrador de um diálogo que permitiria aos órgãos legislativos revisarem suas leis, levando em consideração as decisões dos tribunais. Logo, a objeção contramajoritária ao judicial review não se sustentaria.

Hogg e Bushell partem da premissa de que para haver um diálogo, em uma perspectiva democrática, é necessário que as decisões judiciais declaratórias de inconstitucionalidade de leis possam ser superadas, modificadas ou anuladas pelo processo legislativo ordinário. Em sua pesquisa, constatam que de 65 casos em que a Suprema Corte canadense invalidou leis por contrariarem a Constituição, em 44 deles (2/3) o respectivo órgão legislativo modificou a lei impugnada. Na maior parte dos casos, pequenas mudanças eram suficientes para adequar a legislação aos termos constitucionais, sem comprometer os seus objetivos. ${ }^{20}$

É importante observar que Hogg e Bushell mencionam quatro mecanismos da Constituição do Canadá que permitem ao Legislativo reagir a decisões judiciais que invalidam leis por considerá-las inconstitucionais, cabendo aqui destacar os dois mais importantes deles. Um deles é a chamada cláusula do "não obstante" ("notwithstanding clause"), prevista na seção 33 da Carta e multicitada pelos autores que tratam do tema, que confere aos órgãos legislativos o poder de superação legislativa ("power of legislative override") e consiste, nas palavras dos autores, na "maneira mais óbvia e direta de superar uma decisão judicial". ${ }^{21} \mathrm{O}$ segundo instrumento, não tão lembrado pela doutrina quanto o primeiro, é o mecanismo previsto na seção 1 da Constituição ("Iimitation clause"), igualmente importante para a promoção de uma interlocução entre Legislativo e Judiciário, e que na prática é a forma mais frequente de diálogo entre essas instituições.

A seção 33 da Constituição canadense autoriza que o órgão legislativo inclua em uma lei uma disposição que reafirme expressamente a sua validade não obstante o que dispõem os direitos previstos na seção 2 ou nas seções 7 a 15 da Carta de Direitos e Liberdades de 1982, permitindo ao legislador, nos casos em que a lei tiver sido declarada inconstitucional judicialmente, reeditar a lei original sem a interferência dos tribunais, com validade de 5 anos. Após o decurso do prazo, o Legislativo poderá reeditar o ato pelo mesmo período, o que ensejará uma renovação do debate acerca da matéria. O uso desse poder de superação legislativa se demonstrou bastante escasso em razão

20 HOGG, Peter W.; BUSHELL, Allison A. The Charter dialogue between courts and legislatures (or perhaps the Charter of Rights isn't such a bad thing after all). The Osgoode Hall Law Journal, Toronto, v. 35, n. 1, p. 75-124, 1997. p. 80.

21 HOGG, Peter W.; BUSHELL, Allison A. The Charter dialogue between courts and legislatures (or perhaps the Charter of Rights isn't such a bad thing after all). The Osgoode Hall Law Journal, Toronto, v. 35, n. 1, p. 75-124, 1997. p. 83. 
de um ambiente político de resistência ao seu emprego, havendo normalmente referência a uma única experiência emblemática em que foi utilizado (Ford vs. Quebec).22

Outro mecanismo ensejador de diálogo mencionado pelos autores é a seção 1 da Carta, segundo a qual os direitos nela previstos estão sujeitos a "limites razoáveis estabelecidos por lei que possam se justificar notoriamente em uma sociedade livre e democrática" ("limitation clause"). Com base nesse dispositivo, o legislador poderá estabelecer limitações razoáveis aos direitos e liberdades fundamentais, ao passo que os tribunais poderão analisar se a medida restritiva a direitos fundamentais imposta pela lei: (i) se trata de um meio voltado a atingir um fim legítimo (teste de legitimidade); (ii) está racionalmente relacionada a esse fim (teste de racionalidade); (iii) se trata da medida menos restritiva ao direito para atingir aquele fim (teste de necessidade); (iv) gera consequências desproporcionais sobre as pessoas que serão afetadas (teste de proporcionalidade). ${ }^{23}$ No caso de a lei não passar em um dos testes e vir a ser declarada inconstitucional pelos tribunais, caberá ao órgão legislativo levar em consideração as razões trazidas pelo Judiciário, para então decidir se irá adaptar a lei para atingir o fim pretendido, modificá-la para adotar uma medida menos restritiva ao direito, ou em último caso, se for uma das hipóteses cabíveis, recorrer à seção 33 e utilizar o seu power of legislative override para superar normativamente a decisão da Corte, por meio da reedição da lei com a inserção da cláusula do "não obstante".24

Nesse ponto, Kent Roach afirma que estão equivocados os que pensam que a proposta de diálogos é infrutífera em razão do pouco uso, pelo Legislativo, do poder de superação da seção 33. É preciso, na realidade, explorar as potencialidades do mecanismo previsto na seção 1 - em geral muito menos lembrado do que o da seção 33 - como forma principal e frequente de diálogo. Sustenta o autor que haverá um diálogo ordinário quando os tribunais se manifestarem sobre a razoabilidade das leis limitadoras de direitos fundamentais, nos termos da seção 1 da Constituição, abrindo ensejo para que o Legislativo amplie o debate para rediscutir as medidas restritivas de direitos que foram adotadas, levando em conta as contribuições dadas à discussão pelo Judiciário, para verificar se é o caso de modificar e adequar a legislação. Tanto os tribunais quanto

22 O caso ocorreu no Quebec. A Suprema Corte declarou inconstitucional uma lei que proibia a utilização de outros idiomas que não o francês em cartazes comerciais. O Legislativo posteriormente reeditou a lei, proibindo o uso de outras línguas para além do francês em cartazes ao ar livre (mas permitindo em cartazes fixados em ambientes fechados) e protegendo-a com a cláusula do "não obstante".

23 Esses quatros testes de constitucionalidade das limitações impostas pela lei aos direitos e liberdades constitucionais foram forjados pela jurisprudência da Suprema Corte canadense no caso R. v. Oakes, de 1986. TREMBLAY, Luc. The legitimacy of judicial review: the limits of dialogue between courts and legislatures. International Journal of Constitutional Law, Oxford, n. 4, v. 3, p. 617-648, 2005. p. 618.

24 HOGG, Peter W.; BUSHELL, Allison A. The Charter dialogue between courts and legislatures (or perhaps the Charter of Rights isn't such a bad thing after all). The Osgoode Hall Law Journal, Toronto, v. 35, n. 1, p. 75-124, 1997. p. 84-85. 
os legisladores trarão, cada qual, aportes diferentes e complementares a respeito das medidas restritivas de direitos. Seria, pois, uma modalidade habitual de diálogo. ${ }^{25}$

Porém, se o Legislativo decidir dar ao Judiciário uma "resposta na sua cara" ("in your face reply"), dizendo que a interpretação constitucional conferida pela Corte estava equivocada ou era inaceitável sob o ponto de vista da maioria do povo, ele poderá reeditar a lei inconstitucional contrariando expressamente a posição do tribunal, surgindo uma hipótese de diálogo extraordinário. Roach sustenta que quando a conversa entre os Poderes chega a esse nível, haverá uma "batalha de gritos" ("shouting match"), e o Judiciário só deverá aceitar essa forma excepcional de resposta, que implica superação legislativa da interpretação da Constituição dada pela Corte, se a prerrogativa de override da seção 33 da Carta for utilizada. Isso porque, quando o diálogo se tornou uma "batalha de gritos", a faculdade prevista na seção 33 tem a qualidade de alertar o povo de que o Legislativo está superando a decisão constitucional do Judiciário em seu nome, e que o ponto de vista da Corte ficará suspenso durante o prazo de 5 anos, até que o ato normativo reeditado expire, o conflito já tenha arrefecido e os ânimos estejam mais calmos para se debater se a lei deve ser mantida ou se a interpretação judicial deve prevalecer. ${ }^{26}$

Ainda que o Parlamento tenha vencido a batalha no grito, ele terá uma oportunidade de rever a questão em um momento de serenidade, após o decurso do período de 5 anos, possibilitando uma segunda análise mais sóbria a respeito do assunto. Caso não seja reeditada a lei, a posição da Corte persistirá como uma interpretação válida da Constituição, seja porque funcionou como um fator levado em conta no debate sobre a reedição ou não da lei após os 5 anos, seja porque operará como um precedente para os tribunais de instâncias inferiores, que poderão declarar inconstitucional a lei que havia sido reeditada pelo Legislativo como uma "resposta na sua cara" ao Judiciário. ${ }^{27}$

A perspectiva do que vem a ser um diálogo institucional entre Legislativo e Judiciário, na visão de Hogg e Bushell, é bastante ampla. Em seu entendimento, existirá um diálogo nos "casos em que uma decisão judicial que anulou uma lei com base em fundamentos constitucionais foi sucedida por uma atuação do respectivo órgão legislativo. Em todos esses casos, deve ter havido considerações sobre a decisão judicial pelo governo e deve ter sido tomada uma decisão de como reagir a ela".28 Entre as situações

\footnotetext{
$25 \mathrm{ROACH}$, Kent. Constitutional and Common Law dialogues between the Supreme Court and Canadian legislatures. Canadian Bar Review, Ottawa, v. 80, n. 1-2, p. 481-533, mar./jun. 2001. p. 486.

$26 \mathrm{ROACH}$, Kent. Constitutional and Common Law dialogues between the Supreme Court and Canadian legislatures. Canadian Bar Review, Ottawa, v. 80, n. 1-2, p. 481-533, mar./jun. 2001. p. 487 e 525.

$27 \mathrm{ROACH}$, Kent. Constitutional and Common Law dialogues between the Supreme Court and Canadian legislatures. Canadian Bar Review, Ottawa, v. 80, n. 1-2, p. 481-533, mar./jun. 2001. p. 487 e 525.

28 HOGG, Peter W.; BUSHELL, Allison A. The Charter dialogue between courts and legislatures (or perhaps the Charter of Rights isn't such a bad thing after all). The Osgoode Hall Law Journal, Toronto, v. 35, n. 1, p. 75-124, 1997. p. 82.
} 
examinadas pelos autores, encontram-se casos em que o Legislativo simplesmente revogou a lei reputada inconstitucional, aceitando a posição do tribunal, além de situações em que o órgão se limitou a modificar a lei para corrigir os problemas apontados pela decisão judicial. Hogg e Bushell consideram que excluir tais hipóteses do conceito ora analisado seria adotar uma visão muito estreita e limitada do que é um diálogo, afinal, o resultado de um diálogo sempre poderá ser um acordo entre os interlocutores. ${ }^{29}$

A teoria canadense dos diálogos institucionais, desenvolvida por Peter Hogg e Allison Bushell e refinada por autores como Kent Roach, foi objeto de críticas por diversos segmentos da doutrina, com base em múltiplos argumentos, ${ }^{30}$ tendo sido revisitada por eles dez anos depois. ${ }^{31}$ Não é objeto deste artigo analisar todas as críticas e respectivas respostas. Para os fins a que se propõe este estudo, ganha relevo a crítica apontada por Luc Tremblay em relação à concepção de diálogos constitucionais descrita nas linhas anteriores.

Em relação à construção teórica de Hogg e Bushell, Luc Tremblay aponta a existência de limites à capacidade de os diálogos institucionais legitimarem democraticamente o controle jurisdicional de constitucionalidade das leis. Embora ele reconheça que possa haver diálogos entre tribunais e órgãos legislativos, o tipo de diálogo que seria necessário para conferir legitimidade ao instituto da judicial review não existe e não tem como existir. Por esse motivo, considera que em última instância a teoria dos diálogos institucionais é meramente retórica. Para chegar a essa conclusão, o autor apresenta duas concepções distintas de diálogo: (a) diálogo como conversa; e (b) diálogo como deliberação. ${ }^{32}$

O (a) diálogo como conversa pressupõe ao menos dois interlocutores trocando impressões, pensamentos e opiniões de maneira informal e espontânea. A finalidade é simplesmente explorar um assunto, aprender algo novo, identificar novas perspectivas, tal como ocorre em um almoço entre amigos, em que os diversos temas vêm à tona sem um objetivo específico, sem um debate forte e argumentativo. Ele não se destina a uma tomada de decisão coletiva, a resolver problemas ou apaziguar conflitos, nem a convencer os demais sobre qual argumento é o melhor ou mais adequado. Assim, o diálogo como conversa não possui o condão de legitimar uma decisão, já que o seu

29 HOGG, Peter W.; BUSHELL, Allison A. The Charter dialogue between courts and legislatures (or perhaps the Charter of Rights isn't such a bad thing after all). The Osgoode Hall Law Journal, Toronto, v. 35, n. 1, p. 75-124, 1997. p. 96-98.

30 Por todos, ver: MANFREDI, Christopher P.; KELLY, J. B. Six degrees of dialogue: A response to Hogg and Bushell. The Osgoode Hall Law Journal, Toronto, v. 37, n. 3, p. 513-527, 1999. Sob outro enfoque: LECLAIR, Jean. Réflexions critiques au sujet de la métaphore du dialogue en droit constitutionnel canadien. Revue du Barreau, Montréal, v. 64, num. spécial, p. 377-420, 2003.

31 HOGG, Peter M.; THORNTON, Allison A. Bushell; WRIGHT, Wade K. Charter dialogue revisited: or "much ado about metaphors". The Osgoode Hall Law Journal, Toronto, v. 45, n. 1, p. 1-65, 2007.

32 TREMBLAY, Luc. The legitimacy of judicial review: the limits of dialogue between courts and legislatures. International Journal of Constitutional Law, Oxford, n. 4, v. 3, p. 617-648, 2005. 
escopo não é o de culminar em uma tomada de decisão conjunta, mas simplesmente de realizar um intercâmbio de ideias. ${ }^{33}$

Já o (b) diálogo como deliberação, embora também se caracterize por uma interlocução entre dois ou mais atores, compreendidos como iguais, ele ocorre de forma mais formal e menos espontânea. Nele existem objetivos específicos dos participantes, tais como a elaboração de uma decisão, o alcance de um consenso ou a verificação de qual argumento é o melhor e qual ação deverá ser tomada. Uma assembleia com representantes eleitos seria um exemplo típico desse tipo de diálogo. Ele pressupõe a observância de uma série de condições, tais como: (i) o reconhecimento do outro como igual participante do debate, sem conferir qualquer hierarquia a um deles para decidir nos casos em que houver discordâncias; (ii) a existência de um processo racional de persuasão, sem qualquer tipo de coerção, em que o objetivo não seja ganhar a discussão ou fazer prevalecer o seu ponto de vista; (iii) o propósito de resultar em uma ação ou decisão final que possa ser alvo de um consenso entre os interlocutores, que deverão apresentar e justificar seus argumentos com base em pressupostos racionais e levar em conta os pontos de vista dos demais, tentando incorporá-los em suas perspectivas. No diálogo como deliberação, o processo é desenhado para conferir legitimidade ao resultado final da discussão. ${ }^{34}$

A partir dessa explanação, Tremblay afirma que apenas a segunda espécie (b) diálogo como deliberação - seria capaz de legitimar democraticamente o controle jurisdicional de constitucionalidade das leis com base nos argumentos da teoria dos diálogos institucionais. Seria preciso que a interação entre Legislativo e Judiciário descrita por adeptos dessa teoria, supostamente capaz de legitimar o judicial review, fosse desenvolvida nos termos de um diálogo como deliberação: com o escopo específico de resultar em uma tomada de decisão coletiva, resolvendo conflitos e atingindo consensos, em que cada interlocutor fosse considerado como um igual falante, sem hierarquia, em um intercâmbio de ideias voltado à persuasão, sem um espírito de disputa, no qual cada um estivesse aberto a levar em consideração os argumentos racionais do outro. Entretanto, segundo o autor, não é esse tipo de diálogo que ocorre na dinâmica entre legisladores e tribunais. As interações entre tais instituições ocorrem em um ambiente diverso, no qual dois atores institucionais divergem a respeito da interpretação constitucional e, a partir disso, trocam ideias, opiniões, visões, experiências, sem que esteja presente um objetivo de atingirem um acordo ou chegarem a uma decisão comum,

33 TREMBLAY, Luc. The legitimacy of judicial review: the limits of dialogue between courts and legislatures. International Journal of Constitutional Law, Oxford, n. 4, v. 3, p. 617-648, 2005. p. 630-631.

34 TREMBLAY, Luc. The legitimacy of judicial review: the limits of dialogue between courts and legislatures. International Journal of Constitutional Law, Oxford, n. 4, v. 3, p. 617-648, 2005. p. 631-632. 
não se tratando de um processo desenhado para fins de atribuir legitimidade a determinadas decisões ou ações do Poder Público. ${ }^{35}$

As considerações até aqui apresentadas consistem em importantes ferramentais para analisar o fenômeno da interação entre o Supremo Tribunal Federal brasileiro e a superação normativa de suas decisões por meio de emendas constitucionais pelo Congresso Nacional. ${ }^{36}$ Isso porque, diante de um sistema forte de controle de constitucionalidade e carregado de uma série de objeções, o Congresso Nacional tem adotado as estratégias que estão ao seu alcance para reagir às deliberações do Supremo Tribunal Federal mediante um fenômeno denominado por alguns autores como "emenda constitucional corretiva da jurisprudência", "emenda desafiadora de jurisprudência", "ativismo congressual" 37 ou "correção legislativa da jurisprudência". ${ }^{38}$ Como resposta às decisões da Corte, um dos caminhos seguidos pelo Legislativo tem sido a aprovação de emendas à Constituição como forma de resgatar para arena democrática a discussão de temas relevantes já deliberados, supostamente em última instância, pelo Supremo Tribunal Federal.

\section{AS EMENDAS CONSTITUCIONAIS COMO MECANISMO UTILIZA- DO PELO CONGRESSO NACIONAL BRASILEIRO PARA SUPERAR AS DECISÕES DO SUPREMO TRIBUNAL FEDERAL}

Cumpre, neste momento, averiguar se a principal estratégia utilizada pelo Poder Legislativo brasileiro - a aprovação de emendas constitucionais que superam as decisões do STF - pode ou não ser considerada como uma modalidade dialógica entre tais atores, apta a oxigenar democraticamente o sistema constitucional nacional fortemente centrado no Poder Judiciário.

35 TREMBLAY, Luc. The legitimacy of judicial review: the limits of dialogue between courts and legislatures. International Journal of Constitutional Law, Oxford, n. 4, v. 3, p. 617-648, 2005. p. 634; 644-647.

36 Há, no entanto, outras perspectivas de adoção da ideia de diálogos institucionais, como, por exemplo, os diálogos entre Cortes nacionais e Cortes Internacionais (AGUILAR CAVALLO, Gonzalo. Juiz constitucional e diálogo jurisdicional multinível: a experiência chilena. Revista de Investigações Constitucionais, Curitiba, vol. 6, n. 1, p. 61-89, jan./abr. 2019; RESENDE, Augusto César Leite de; MOLINARO, Carlos Alberto. A interamericanização do direito administrativo sancionador brasileiro: reflexões sobre o princípio da tipicidade da infração disciplinar a partir do diálogo judicial internacional. A\&C - Revista de Direito Administrativo \& Constitucional, Belo Horizonte, ano 19, n. 76, p. 153-173, abr./jun. 2019) ou diálogos entre órgãos do Poder Judiciário e do Poder Executivo (MARIANO, Cynara Monteiro; FURTADO, Emanuel Teófilo; ALBUQUERQUE, Felipe Braga; PEREIRA Fabrícia Helena Linhares Coelho da Silva. Diálogos Sanitários Interinstitucionais e a experiência de implantação do NAT-JUS. Revista de Investigações Constitucionais, Curitiba, vol. 5, n. 1, p. 169-188, jan./abr. 2018; MANEIRO, Renata de Marins Jaber; PULCINELLI, Eliana. Litígio estratégico, vinculação de precedentes e abertura ao diálogo constitucional na construção do provimento jurisdicional. Revista de Investigações Constitucionais, Curitiba, vol. 4, n. 2, p. 193-219, maio/ago. 2017).

37 BRASIL. Supremo Tribunal Federal. ADI n. 5.105. Relator Min. Luiz Fux. Plenário. Julgamento em 01.10.2015.

38 ANTONELLI, Leonardo Pietro. Correção legislativa da jurisprudência: uma análise das emendas constitucionais em matéria tributária. Rio de Janeiro: Editora JC, 2015. 
Conforme visto nos tópicos precedentes, há distintas saídas para o Poder Legislativo reagir quando discorda das decisões do Poder Judiciário que interpretam a Constituição, como forma de reverter a posição sedimentada judicialmente. Alguns sistemas preveem mecanismos destinados a esse fim, como é o caso já visto da override clause da seção 33 da Constituição canadense, que enseja uma dinâmica peculiar, inclusive com prazo de validade para a lei reeditada que excepcionou explicitamente a incidência de previsões constitucionais. Porém, nos ordenamentos jurídicos em que instrumentos como esse não são previstos de modo expresso, há também a possibilidade de superação do entendimento jurisprudencial pelo Legislativo mesmo que sem previsão normativa específica para tanto, especialmente mediante dois caminhos: (i) a reedição de lei já declarada inconstitucional pelo Judiciário; (ii) a aprovação de emenda à Constituição que supere a decisão judicial.

Tanto nos Estados Unidos quanto no Brasil há exemplos das duas situações. ${ }^{39}$ São diversos e interessantes os casos de edição de leis que contrariam a jurisprudência constitucional dos tribunais, prática que suscita posições divergentes na doutrina e na jurisprudência quanto à validade de tais diplomas legais. ${ }^{40}$ Contudo, o recorte metodológico deste estudo delimita como objeto de exame a questão da reversão das decisões declaratórias de inconstitucionalidade do Supremo Tribunal Federal por meio de emendas constitucionais.

Na experiência estadunidense, é muito mais comum a tentativa de reversão do entendimento jurisprudencial por meio da aprovação de leis ordinárias, diante da existência de regras muito mais rígidas para a aprovação de emendas à Constituição (que exigem ratificação pelas legislaturas de $3 / 4$ dos Estados), sendo apenas 4 os casos em que essa via foi adotada pelo Congresso para superar um precedente da Suprema Corte. ${ }^{41}$ São eles: (i) a Décima Primeira Emenda superou o precedente Chisholm v. Georgia (1793), sobre a competência dos juízes federais para julgar ações de cidadãos de um Estado-membro contra outro Estado-membro; (ii) a Décima Terceira e a Décima Quarta Emendas superaram o precedente Dred Scott v. Sanford (1857), sobre escravidão e direito de cidadania; (iii) a Décima Sexta Emenda superou o precedente Pollock v. Farmers Loan \& Trust Co. (1895), sobre a proporcionalidade do imposto sobre a renda; e

\footnotetext{
39 Nos Estados Unidos, ver: OLIVEIRA, Gustavo da Gama Vital de. Diálogo constitucional e correção legislativa da jurisprudência no direito tributário brasileiro. 2009. 252 f. Dissertação (Mestrado) - Universidade Estadual do Rio de Janeiro, Faculdade de Direito. Rio de Janeiro, 2009. p. 32-37.

40 O tema foi analisado por: VICTOR, Sérgio Antônio Ferreira. Diálogo institucional, democracia e Estado de Direito: o debate entre o Supremo Tribunal Federal e o Congresso Nacional sobre a interpretação da Constituição. 2013. 200 f. Tese (Doutorado) - Universidade de São Paulo, Faculdade de Direito. São Paulo, 2013. p. 177-182; BRANDÃO, Rodrigo. Supremacia judicial versus diálogos constitucionais: a quem cabe a última palavra sobre o sentido da Constituição? Rio de Janeiro: Lumen Juris, 2012. p. 300-308.

41 BLACKSTONE, Bethany. An analysis of policy-based congressional responses to the U.S. Supreme Court's constitutional decisions. Law \& Society Review, Salt Lake City, v. 47, n. 1, p. 199-228, 2013. p. 200.
} 
(iv) a Vigésima Sexta Emenda superou o precedente Oregon v. Mitchell (1970), sobre a competência do Congresso para estabelecer regras eleitorais para os Estados-membros. ${ }^{42} \mathrm{Em}$ tais casos, pode-se dizer que houve aceitação da Suprema Corte em relação às modificações constitucionais, que passaram a ser respeitadas e aplicadas.

No caso do sistema brasileiro, o ordenamento jurídico é claro ao estabelecer que as decisões do Supremo Tribunal Federal em sede de controle de constitucionalidade produzem efeitos vinculantes à Administração Pública e aos demais órgãos do Poder Judiciário, não fazendo qualquer alusão ao Poder Legislativo (art. 102, §2 e art. 103-A da Constituição Federal; ${ }^{43}$ art. 28, parágrafo único da Lei n. 9.868/1999). ${ }^{44}$ Assim, sob o ponto de vista da literalidade dos enunciados normativos constitucionais e legais que tratam do tema, não há qualquer óbice à edição de novos atos normativos - sejam eles leis ou emendas à Constituição - que discrepem de decisões já assentadas pela Suprema Corte brasileira em matéria constitucional.

A questão é saber se, na prática, as emendas à Constituição com nítido propósito de superar a jurisprudência do STF seriam ou não uma manifestação de diálogo institucional à luz das teorias dialógicas anteriormente apresentadas. Um dado deve ser desde já sublinhado: no Brasil, a aprovação de emendas à Constituição tem funcionado pelo menos com uma forma de reacender o debate de questões constitucionais no seio da arena política, na medida em que permite que leituras do sistema constitucional realizadas pela Suprema Corte sejam trazidas para a esfera de debate democrático e rediscutidas.

Considerando os limites que a pesquisa científica desenvolvida no âmbito de um artigo impõe ao investigador, não foi possível realizar uma análise minudente e detalhada de todas as decisões do Supremo Tribunal Federal que provocaram reações do

42 CHRISTIANSEN, Matthew R.; ESKRIDGE JR., William N. Congressional overrides of Supreme Court statutory interpretation decisions, 1967-2011. Texas Law Review, Austin, v. 92, n. 6, p.1317-1541, 2014. p. 1335, nota 71; OLIVEIRA, Gustavo da Gama Vital de. Diálogo constitucional e correção legislativa da jurisprudência no direito tributário brasileiro. 2009. 252 f. Dissertação (Mestrado) - Universidade Estadual do Rio de Janeiro, Faculdade de Direito. Rio de Janeiro, 2009. p. 26-31.

43 Constituição da República Federativa do Brasil de 1988: "Art. 103. (...) §2 As decisões definitivas de mérito, proferidas pelo Supremo Tribunal Federal, nas ações diretas de inconstitucionalidade e nas ações declaratórias de constitucionalidade produzirão eficácia contra todos e efeito vinculante, relativamente aos demais órgãos do Poder Judiciário e à administração pública direta e indireta, nas esferas federal, estadual e municipal. (...) Art. 103-A. O Supremo Tribunal Federal poderá, de ofício ou por provocação, mediante decisão de dois terços dos seus membros, após reiteradas decisões sobre matéria constitucional, aprovar súmula que, a partir de sua publicação na imprensa oficial, terá efeito vinculante em relação aos demais órgãos do Poder Judiciário e à administração pública direta e indireta, nas esferas federal, estadual e municipal, bem como proceder à sua revisão ou cancelamento, na forma estabelecida em lei".

44 Lei n. 9.868/1999: "Art. 28. (...) Parágrafo único. A declaração de constitucionalidade ou de inconstitucionalidade, inclusive a interpretação conforme a Constituição e a declaração parcial de inconstitucionalidade sem redução de texto, têm eficácia contra todos e efeito vinculante em relação aos órgãos do Poder Judiciário e à Administração Pública federal, estadual e municipal". 
Congresso Nacional na forma de emendas constitucionais. ${ }^{45}$ Por essa razão, foram selecionados cinco casos para exame. O critério de escolha consubstanciou-se em situações em que o Congresso Nacional promulgou Emendas à Constituição (EC) como uma nítida "resposta na sua cara" ("in your face reply"), ${ }^{46}$ visando a superar a jurisprudência do STF entendida como equivocada ou inaceitável sob a visão popular.

(a) Taxas de iluminação pública municipais - RE n. 233.332 e EC n. 39/2002: o STF, no julgamento do Recurso Extraordinário n. 233.332, declarou inconstitucionais leis municipais que instituíam cobrança de iluminação pública sob a espécie tributária de taxa. De acordo com o Tribunal, a taxa somente poderia ser cobrada como contrapartida de serviços públicos específicos e divisíveis, nos termos do art. 145, II da CF/1988. No seu entendimento, a iluminação pública não preenchia nenhum dos dois requisitos, de modo que o custeio desse serviço não poderia ser remunerado mediante taxa. A decisão, embora aparentemente acertada, cortou uma importante fonte de receita para custear tal serviço, causando um efeito sistêmico indesejado: o desfalque dos cofres públicos municipais. O Congresso, ciente do impacto negativo da decisão sobre os Municípios, aprovou a EC n. 39/2002, que inseriu no texto constitucional o art. 149-A, o qual passou a permitir aos Municípios e ao Distrito Federal a instituição e cobrança de "contribuição para o custeio da iluminação pública". Interessante observar que o Congresso trouxe no parecer pela aprovação da EC n. 39/2002 a menção expressa ao posicionamento do STF e a sua fundamentação, bem como apresentou a justificativa déficit de arrecadação dos Municípios - pela qual era necessária a adequação do texto constitucional para admitir a possibilidade de cobrança do serviço pelos Municípios, ainda que por uma espécie de tributo distinta. ${ }^{47}$

(b) Fixação do número de vereadores das Câmaras Municipais - RE n. 197.917 e EC n. 58/2009: no julgamento do Recurso Extraordinário n. 197.917, o STF entendeu, com base no texto do art. 29 da CF/1988, que para se identificar o número de vereadores de cada Município era necessário realizar um cálculo aritmético considerando a população

45 Sobre tema, com exemplos em matéria tributária, ver: CUNHA, Carlos Renato; COSTA, Valterlei A. da; VALLE, Maurício Dalri Timm do. O sobrestamento legislativo de decisões do STF: diálogo constitucional e o papel do judiciário como ator com poder de veto no Brasil. A\&C - Revista de Direito Administrativo \& Constitucional, Belo Horizonte, ano 18, n. 74, p. 193-216, out./dez. 2018.

46 Para retomar a expressão cunhada por ROACH, Kent. Constitutional and Common Law dialogues between the Supreme Court and Canadian legislatures. Canadian Bar Review, Ottawa, v. 80, n. 1-2, p. 481-533, mar./jun. 2001. p. 487.

47 "Os Municípios há muito vêm lutando com a carência de recursos públicos para custear tal serviço de inelutável necessidade para o bem-estar e a segurança das suas populações. Muitos haviam criado uma taxa de iluminação pública, que reiteradamente tem sido fulminada pelo Supremo Tribunal Federal como inconstitucional, porque não atende aos requisitos da especificidade e divisibilidade do serviço, prestado ao contribuinte ou posto a sua disposição, desobedecendo aos estritos parâmetros de definição da taxa, estabelecidos no inciso II do art. 145, cujo parágrafo $2^{\circ}$ também proíbe que a taxa tenha base de cálculo própria de impostos". (BRASIL. Câmara dos Deputados. Parecer do Relator Dep. Custódio Mattos pela aprovação das PECs - 559/2002 e 504/2002. Disponível em: <http://www.camara.gov.br/proposicoesWeb/prop_mostrarintegra?codteor $=85426 \&$ filename $=$ Tramitacao $-P E C+559 / 2002>$. Acesso em 24 abr. 2020) 
real de cada entidade, o que acabou redundando numa redução do número de vereadores em todo o Brasil. ${ }^{48}$ Para o Ministro Relator, havia "um verdadeiro escândalo por parte de alguns municípios, de algumas Câmaras de Vereadores, que extrapolam as regras do tolerável! Municípios de três mil habitantes, ou em torno disso, por exemplo, possuem quinze, dezesseis vereadores, e vai por aí". ${ }^{49} \mathrm{~A}$ reação por parte do Congresso Nacional foi imediata, elaborando e aprovando a EC n. 58/2009, que conferiu nova redação ao art. 29 da CF/1988, estabelecendo os números mínimo e máximo de vereadores, proporcional ao número de eleitores, contrariando o entendimento firmado pelo STF. No relatório avulso sobre a proposta que redundou na emenda à Constituição, consta menção expressa à decisão do STF e à sua consequência indesejada: redução em quase nove mil o número de membros das Câmeras Municipais em todo o país, o que traria prejuízos ao próprio regime democrático. ${ }^{50}$ No parecer da Comissão Especial, o relator da PEC consignou expressamente qual era o seu objetivo: "a proposição principal, em adição, vem resolver o que sempre considerei não apenas um erro de apreciação da autoridade judicial, mas uma grande injustiça para com o Poder Legislativo Municipal".51

(c) Teto remuneratório dos servidores públicos - ADI n. 14 e EC n. 19/1998 e MS n. 24.875 e EC n. 41/2003: o STF, no julgamento da ADI n. 14, ${ }^{52}$ que questionava o alcance da restrição do teto remuneratório dos servidores públicos previsto no art. 37, XI da CF/1988, fixou entendimento de que tal limitação englobava apenas os vencimentos do agente público, não alcançando as vantagens pessoais recebidas por cada categoria. Passados dez anos, o Congresso Nacional promulgou a EC n. 19/1998, que incluiu no limite remuneratório as vantagens de caráter pessoal dos servidores. No entanto, em sessão administrativa ocorrida em 24.06.1998, o STF entendeu que a nova disposição constitucional, para ser aplicada, necessitava de regulamentação mediante lei ordinária de iniciativa conjunta do Presidente da República, das Casas Legislativas e do STF, como determinava o artigo 48, XV da CF/1988, e na mesma oportunidade determinou que, até a efetiva regulamentação, seria aplicado o texto constitucional em sua redação originária. Passados cinco anos, o Congresso reagiu novamente e aprovou a EC n. 41/2003, estabelecendo que a regulamentação do teto constitucional previsto na EC n. 19/1998 não seria mais por meio de projeto de lei de iniciativa conjunta, admitindo a sua autoaplicabilidade, e afastando a possibilidade de invocação de direito adquirido

\footnotetext{
48 O Tribunal Superior Eleitoral, por meio da Resolução n. 21.702/2004, estendeu o entendimento do Supremo Tribunal Federal no Recurso Extraordinário n. 197.917 para todo os Municípios do país.

49 BRASIL. Supremo Tribunal Federal. RE n. 197.917. Rel. Min. Maurício Corrêa. Julgado em 24/03/2004.

50 BRASIL. Senado Federal. Parecer avulso do Relator Dep. Jefferson Peres. Disponível em: <http://legis.senado.leg.br/sdleg-getter/documento?dm=4801236\&disposition=inline>. Acesso em 24 abr. 2020.

51 BRASIL. Câmara dos Deputados. Parecer do Relator Dep. Arnaldo Faria de Sá pela aprovação da PEC n. 379 , de 2009. Disponível em: < http://www.camara.gov.br/sileg/integras/684194.pdf>. Acesso em 24 abr. 2020.

52 BRASIL. Supremo Tribunal Federal. ADI n. 14. Rel. Min. Célio Borja. Tribunal Pleno. Julgado em 28/09/1989.
} 
contra a sua incidência..$^{53}$ Além disso, estabeleceu que a nova regra do teto remuneratório seria aplicada globalmente a todos os servidores, inclusive aos ativos na data da sua promulgação. O STF, no julgamento do Mandado de Segurança n. 24.875, em nova reação à deliberação do Congresso Nacional, afastou a incidência do novo teto remuneratório em relação aos servidores que receberiam acima do teto constitucional antes da promulgação da EC n. 41/2003. Segundo o Tribunal, a aplicação do novo teto aos servidores ativos levaria a uma redução remuneratória, ofendendo o artigo $5^{\circ}$, inciso XXXVI, da CF/1988, que estabelece a garantia fundamental do direito adquirido. ${ }^{54} \mathrm{Nessa}$ hipótese, nenhum dos Poderes observou as razões lançadas pelo outro, caracterizando uma verdadeira sobreposição de monólogos.

(d) Progressividade do Imposto Predial e Territorial Urbano (IPTU) - RE n. 153.771 e EC n. 29/2000: o STF, no julgamento do Recurso Extraordinário n. 153.771, declarou serem inconstitucionais as leis municipais que fixavam alíquota progressiva do IPTU com base no valor venal do imóvel. Segundo a Corte, o art. 182 da CF/1988 somente autoriza a fixação de alíquotas progressivas para a finalidade extrafiscal de incentivar a adequação do uso da propriedade urbana à sua função social. ${ }^{55} \mathrm{Em}$ clara afronta à decisão da Suprema Corte, o Congresso Nacional promulgou a EC n. 29/2000, que alterou a redação do art. 156, § $1^{\circ}$ da CF/1988, passando o texto constitucional a autorizar expressamente a hipótese de cobrança progressiva do IPTU com base no valor venal do imóvel. No caso, não houve um intercâmbio argumentativo entre Congresso e STF. A decisão da Corte julgou as leis municipais com base na violação literal ao texto constitucional e a única resposta do Parlamento foi alterar a redação da Constituição para superar o entendimento do Judiciário.

(e) Prática da vaquejada - ADI n. 4.983 e EC n. 96/2017: o STF, instado pelo Procurador-Geral da República por meio da ADI n. 4.983, consignou que a prática da vaquejada seria incompatível com o direito à proteção ao meio-ambiente e o dever do Poder Público de proteger os animais contra práticas que os submetam a crueldade (art. 225, caput e $\S 1^{\circ} \mathrm{VII}$ da CF/1988)..$^{56}$ Entendeu que tal direito prevaleceria sobre os valores cul-

\footnotetext{
53 BRASIL. Câmara dos Deputados. Exposição de motivos da EMC 41-2003. Disponível em: <http://www2. camara.leg.br/legin/fed/emecon/2003/emendaconstitucional-41-19-dezembro-2003-497025-anexo-pl.pdf>. Acesso em 24 abr. 2020.

54 BRASIL. Supremo Tribunal Federal. MS n. 24875. Rel. Min. Sepúlveda Pertence. Tribunal Pleno. Julgado em $11 / 05 / 2006$.

55 BRASIL. Supremo Tribunal Federal. RE n. 153.771. Rel. Min. Moreira Alves. Tribunal Pleno. Julgado em 20/11/1996.

56 Sobre o tema, ver: LOPES FILHO, Juraci Mourão; CIDRÃO, Taís Vasconcelos. A (in)constitucionalidade da vaquejada: desacordos, integridade e backlash. Revista de Direito Econômico e Socioambiental, Curitiba, v. 9, n. 3, p. 119-160, set./dez. 2018; CICHELERO, César Augusto; FERRI, Caroline; NUNES, Eduardo Brandão. From an idealized separation of powers to its practical problems in the Rule of Law. Revista de Investigações Constitucionais, Curitiba, vol. 5, n. 1, p. 15-40, jan./abr. 2018; LEAL, Mônia Clarissa Hennig; MORAES, Maria Valetina de. "Diálogo" entre Poderes no Brasil? Da inconstitucionalidade da regulação da vaquejada à vaquejada
} 
turais representado por essa prática, declarando inconstitucional a Lei n. 15.299/2013 do Estado do Ceará, que regulamentava a vaquejada como prática desportiva. ${ }^{57} \mathrm{O}$ julgamento foi realizado em 6 de outubro de 2016. Em 19 de outubro de 2016, antes mesmo da publicação do acordão do STF, o Parlamento apresentou proposta de Emenda à Constituição para alterar o texto constitucional e estabelecer que não se consideravam cruéis as manifestações culturais definidas na Constituição e registradas como bens de natureza imaterial integrantes do patrimônio cultural brasileiro. O Congresso Nacional, em 6 de junho de 2017, ou seja, em menos de um ano do julgamento do STF, promulgou EC n. 96/2017, que acrescentou o $\S 7^{\circ}$ ao art. 225, da CF/1988, passando a permitir práticas como as vaquejadas e o rodeio em todo o país. A proposta inicial apresentada trouxe explicitamente em suas razões que "Em que pese não ter sido sequer publicado o acórdão, a notícia da decisão tomada pela Suprema Corte suscitou intensa polêmica entre os apoiadores da prática e os defensores dos direitos animais, e chegou mesmo a ensejar o anúncio da formação de uma Frente Parlamentar em Defesa da Vaquejada. Dessarte, a fim de encerrar a controvérsia que ainda cerca a questão, propõe-se a presente sugestão de emenda ao texto constitucional (...)".58

Interessante notar que a proposta que originou a EC n. 96/2017 foi submetida a consulta pública no site do Senado e recebeu 63.405 votos contrários e apenas 17.727 favoráveis..$^{59}$ Por outro lado, nas razões expostas no parecer da Comissão de Constituição, Justiça e Cidadania, consta o seguinte argumento em favor da alteração normativa: "devemos acolher o pluralismo cultural que é peculiar ao Brasil e proteger essas formas de manifestação cultural. Caso seja proibida a vaquejada, retiraríamos das populações rurais do País, especialmente as das regiões Norte e Nordeste, uma das poucas opções de acesso à cultura e ao lazer que lhes está disponível, além de impactar a economia de municípios interioranos dessas regiões, já combalidos pela atual crise".60 Se for levado em conta o resultado da consulta pública, seria possível afirmar que o Congresso Nacional, neste caso, atuou contrariamente à vontade do povo manifestada por meio daquele mecanismo.

como patrimônio cultural imaterial brasileiro: uma análise crítica. Revista de Investigações Constitucionais, Curitiba, vol. 5, n. 1, p. 63-81, jan./abr. 2018.

57 LOPES FILHO, Juraci Mourão; CIDRÃO, Taís Vasconcelos. A (in)constitucionalidade da vaquejada: desacordos, integridade e backlash. Revista de Direito Econômico e Socioambiental, Curitiba, v. 9, n. 3, p. 119-160, set./dez. 2018.

58 BRASIL. Senado Federal. Proposta de Emenda Constitucional n 50, de 2016. Disponível em: <https://legis. senado.leg.br/sdleg-getter/documento?dm=3035267\&disposition=inline>. Acesso em 24 abr. 2020.

59 BRASIL. Senado Federal. Consulta pública. Resultado apurado em 01.08.2017. Disponível em: <http:// www25.senado.leg.br/web/atividade/materias/-/materia/127262>. Acesso em 24 abr. 2020.

60 BRASIL. Senado Federal. Parecer da Comissão de Constituição, Justiça e Cidadania. PEC n 50, de 2016. Disponível em: <http://legis.senado.leg.br/sdleg-getter/documento?dm=4609589\&disposition=inline >. Acesso em 24 abr. 2020. 


\section{HÁ DIÁLOGOS ENTRE LEGISLATIVO E JUDICIÁRIO NA EXPERI- ÊNCIA BRASILEIRA DE EMENDAS CONSTITUCIONAIS QUE SU- PERAM A JURISPRUDÊNCIA?}

Observados os casos de superação normativa, pelo Poder Legislativo, das decisões declaratórias de inconstitucionalidade do STF por meio de aprovação de emendas à Constituição, cumpre retomar a questão inicial: seriam as situações narradas hipóteses de diálogos constitucionais entre Legislativo e Judiciário, aptos a conferir legitimidade democrática ao sistema forte de controle jurisdicional de constitucionalidade das leis no Brasil? A resposta a esse questionamento depende essencialmente da concepção de diálogo adotada, devendo-se retomar as teorias dialógicas estudadas anteriormente.

Em primeiro lugar, é preciso iniciar pela doutrina dos "diálogos institucionais" construída pioneiramente por Peter Hogg e Allison Bushell. Tais autores, em um dos artigos mais importantes a respeito do tema dos diálogos constitucionais entre Judiciário e Legislativo, questionam: “É possível haver um diálogo entre duas instituições quando uma está tão claramente subordinada à outra? Um diálogo não exige uma relação entre iguais?" Logo após, fornecem a seguinte resposta: "Nos casos em que uma decisão judicial está sujeita à superação, modificação ou anulação legislativa, fará sentido considerar a relação entre a Corte e o órgão legislativo competente como um diálogo".61 E isso porque, a tomada de decisão judicial provoca um debate a respeito de valores constitucionais no qual esses últimos passam a ocupar uma posição mais importante do que se não tivesse sido tomada decisão judicial alguma.

Sob o ponto de vista jurídico-normativo, já se viu que a Constituição e a legislação no Brasil admitem tal hipótese, já que os efeitos das decisões de inconstitucionalidade do STF vinculam apenas a Administração Pública e os demais órgãos do Poder Judiciário, não incidindo sobre o Poder Legislativo. No conceito amplíssimo de diálogo institucional enunciado pelos autores - "casos em que uma decisão judicial que anulou uma lei com base em fundamentos constitucionais foi sucedida por uma atuação do respectivo órgão legislativo"62 - talvez a interação do Congresso Nacional com o STF se enquadrasse. Ocorre que Hogg e Bushell pressupõem expressamente que a superação da decisão levada a efeito pelo Poder Legislativo consistirá em uma resposta que respeitará os valores constitucionais identificados pelo Judiciário, mas que fará com que

\footnotetext{
61 HOGG, Peter W.; BUSHELL, Allison A. The Charter dialogue between courts and legislatures (or perhaps the Charter of Rights isn't such a bad thing after all). The Osgoode Hall Law Journal, Toronto, v. 35, n. 1, p. 75-124, 1997. p. 79. (Tradução livre)

62 HOGG, Peter W.; BUSHELL, Allison A. The Charter dialogue between courts and legislatures (or perhaps the Charter of Rights isn't such a bad thing after all). The Osgoode Hall Law Journal, Toronto, v. 35, n. 1, p. 75-124, 1997. p. 82.
} 
sejam atingidos os objetivos sociais e econômicos da lei que foram bloqueados pela decisão judicial. ${ }^{63} \mathrm{E}$ isso nem sempre acontece da relação entre Parlamento e Suprema Corte na experiência brasileira.

Em casos como o da taxa de iluminação pública, por exemplo, até se poderia dizer que houve um diálogo nesses termos, pois o Legislativo respeitou os requisitos constitucionais que, segundo o STF, eram exigidos para a instituição de uma taxa, criando a possibilidade de instituição de um tributo distinto - a contribuição - para manter o mesmo objetivo, mas sem afrontar a leitura constitucional feita pelo STF. Já no caso envolvendo a instituição de progressividade no IPTU, não houve tentativa do Parlamento de tomar em conta a interpretação da Constituição feita pela Corte. Pelo contrário: a emenda se destinou a inserir no texto constitucional previsão diametralmente oposta ao entendimento jurisprudencial, admitindo expressamente a instituição de IPTU progressivo para fins fiscais, contrariamente ao que decidiu o STF. Assim, pode-se dizer que algumas das situações narradas se encaixariam no conceito amplo de diálogos constitucionais de Hogg e Bushell, como é o caso da taxa de iluminação pública, enquanto outras não, como foi o caso da progressividade do IPTU.

Em segundo lugar, seria possível cogitar se as interações aqui examinadas seriam reputadas autênticos diálogos pela versão refinada da teoria dos diálogos institucionais de Kent Roach. O autor aponta que a solução para conter o ativismo judicial está no ativismo legislativo, compreendido como o conjunto de reações do Parlamento a decisões do Judiciário que, ao declarar as leis inconstitucionais relembrando o Legislativo da importância de valores constitucionais que não foram observados na elaboração da lei, acabam por contribuir para o processo democrático, por exigir dos órgãos legislativos uma postura explícita sobre a restrição ou violação de direitos constitucionais identificada pelo tribunal. Contudo, o Roach ressalta que esse ativismo legislativo se caracteriza por reações dialógicas do Parlamento, que compreendem a edição de novas leis que levem em conta - para concordar ou discordar - a interpretação constitucional realizada pelo Judiciário, sem com isso precisar afrontar a Corte ou modificar a Constituição. ${ }^{64}$

A explicação é dada com base no modelo canadense, no qual, se a discordância entre as duas esferas for tão significativa, caberá o uso da seção 33 da Constituição que permitirá ao Legislativo explicitar a divergência reeditando a lei, e nela inserindo expressamente cláusula que afirme a sua operatividade não obstante o que dispõem as previsões de direitos fundamentais da seção 2 ou das seções 7 a 15, com validade de 5

63 HOGG, Peter W.; BUSHELL, Allison A. The Charter dialogue between courts and legislatures (or perhaps the Charter of Rights isn't such a bad thing after all). The Osgoode Hall Law Journal, Toronto, v. 35, n. 1, p. 75-124, 1997. p. 79-80.

$64 \mathrm{ROACH}$, Kent. Constitutional and Common Law dialogues between the Supreme Court and Canadian legislatures. Canadian Bar Review, Ottawa, v. 80, n. 1-2, p. 481-533, mar./jun. 2001. p. 532. 
anos. Relembre-se que, nesse ponto, Roach ressalta a necessidade de o Parlamento se valer explicitamente de tal mecanismo, já que tal prerrogativa tem o condão de chamar a atenção do povo sobre a manobra legislativa de superar a decisão constitucional judicial e suspender por um período de 5 anos a interpretação de inconstitucionalidade dada pelo Judiciário, permitindo acalmar o clima de acirramento para que, em uma nova oportunidade, seja discutido se a lei em questão deve permanecer válida ou se a leitura feita anterior pelo Judiciário deve se sobrepor. Sem o recurso a esse instrumento e a implementação dessa dinâmica, o autor afirma que a mera discordância frontal de interpretações entre os Poderes implicará uma "batalha de gritos" ("shouting match"). ${ }^{65}$

Se tal premissa for adotada e aplicada ao objeto de estudo deste artigo, as reações do Congresso Nacional brasileiro às decisões declaratórias de inconstitucionalidade do Supremo Tribunal Federal, caracterizadas pela aprovação de emendas à Constituição para afirmar o contrário do que foi dito pelo Judiciário, não seriam em absoluto uma hipótese de diálogo. Elas se aproximariam muito mais daquilo que Roach denominou de "batalha de gritos" ("shouting match"), na qual o Legislativo, sem diálogo, tenta fazer prevalecer a sua interpretação constitucional sobre a do Judiciário. Como visto, o autor é expresso ao asseverar que o diálogo deverá acontecer sem a necessidade de afronta à Corte ou de alteração do texto constitucional.

Em terceiro lugar, caberia verificar em qual das concepções de diálogos descritas por Luc Tremblay se enquadrariam as interlocuções entre Legislativo e Judiciário brasileiros nas situações acima mencionadas. Conforme se explicou anteriormente, o autor descreve duas modalidades de diálogo: (a) diálogo como conversa; e (b) diálogo como deliberação. ${ }^{66}$ A primeira espécie se trata de uma interação despretensiosa, marcada por um intercâmbio de ideias despido de caráter argumentativo, sem qualquer preocupação específica de resultar em uma tomada de decisão, em resolver uma contenda, em solucionar um problema, ou mesmo em gerar um processo de persuasão. Por conta disso, tais diálogos são incapazes de legitimar uma decisão, pois como esse não é o seu propósito, eles não cumprem as exigências necessárias para tanto. A segunda espécie tem como objetivo específico alcançar um acordo, suscitar convencimento, mediante um debate robusto que culmine na tomada de uma decisão a partir da verificação, por ambos os interlocutores, de quais são os melhores argumentos, que conduzirão a uma melhor ação a ser realizada. Logo, o processo se presta a conferir legitimidade à solução adotada. ${ }^{67}$

65 ROACH, Kent. Constitutional and Common Law dialogues between the Supreme Court and Canadian legislatures. Canadian Bar Review, Ottawa, v. 80, n. 1-2, p. 481-533, mar./jun. 2001. p. 487 e 525.

66 TREMBLAY, Luc. The legitimacy of judicial review: the limits of dialogue between courts and legislatures. International Journal of Constitutional Law, Oxford, n. 4, v. 3, p. 617-648, 2005.

67 TREMBLAY, Luc. The legitimacy of judicial review: the limits of dialogue between courts and legislatures. International Journal of Constitutional Law, Oxford, n. 4, v. 3, p. 617-648, 2005. p. 630-632. 
Sob tal perspectiva, as reações do Congresso Nacional às decisões do STF mediante aprovação de emendas à Constituição se revelam muito mais como um diálogo como conversa do que como um diálogo como deliberação. E isso porque essa interação não atende propriamente às exigências impostas a esse segundo tipo de diálogo, tais como: (i) posição de igualdade entre os interlocutores com reconhecimento recíproco, sem que um assuma a posição de guardião da última palavra; (ii) processo racional de convencimento, com abertura aos argumentos e pontos de vistas do debatedor; (iii) escopo determinado de atingir uma decisão final, passível de ser alcançada mediante o convencimento e o estabelecimento de um consenso.

No caso da fixação do número de vereadores das Câmaras Municipais, por exemplo, não houve tentativa de levar em consideração os argumentos trazidos pelo Supremo Tribunal Federal, tendo ocorrido apenas uma sobreposição das razões expostas pelos parlamentares ao entendimento formado pela Corte. O resultado foi uma emenda que alterou a Constituição para fazer prevalecer a voz do Parlamento em detrimento do entendimento do Judiciário. O mesmo se diga em relação ao caso do teto remuneratório dos servidores públicos, em que Legislativo e Judiciário adotaram medidas diametralmente opostas, sem tomar em conta os argumentos de princípios e de políticas públicas trazidos por cada qual em suas manifestações.

O problema desse segundo tipo de diálogo (como conversa), consoante Luc Tremblay, é que ele é incapaz de atribuir legitimidade democrática ao processo do judicial review, por não se tratar de um processo dialógico desenhado para essa finalidade, o que exigiria um propósito determinado de a interação culminar em uma tomada de decisão coletiva, gerando a resolução de um conflito, na qual cada participante fosse reconhecido como igual em uma troca de ideias marcada pela abertura ao convencimento racional. 68

Nesse sentido, Conrado Hübner Mendes aponta ser possível cogitar de duas modalidades de interlocução: "a deliberativa (que fala e escuta, com o objetivo da persuasão), e a adversarial (que fala para se impor). O primeiro está mais exposto publicamente ao argumento, mais aberto ao reconhecimento do diálogo, e mais disposto ao desafio deliberativo".69 Nas situações analisadas no presente estudo, nota-se que em praticamente todos eles - talvez com exceção do caso da taxa de iluminação pública, em que o Legislativo reconheceu que aquela não era a melhor espécie de tributo para atingir aquela finalidade - a reação do Congresso Nacional buscou se sobrepor à conclusão do Supremo Tribunal Federal, sem maiores preocupações com a sua fundamentação. Tratou-se, pois, de uma sobreposição de monólogos, muito mais do que uma verdadeira prática dialógica.

68 TREMBLAY, Luc. The legitimacy of judicial review: the limits of dialogue between courts and legislatures. International Journal of Constitutional Law, Oxford, n. 4, v. 3, p. 617-648, 2005. p. 634; 644-647.

69 MENDES, Conrado Hübner. Direitos fundamentais, separação dos poderes e deliberação. 2008. $267 \mathrm{f}$ Tese de Doutorado em Ciência Política - Departamento de Ciência Política da Faculdade de Filosofia, Letras e Ciências Humanas, Universidade de São Paulo. São Paulo. 2008. p. 219. 
Por outro lado, não se pode negar que a investigação desses casos demonstrou que a dinâmica suscitada pelo controle jurisdicional de constitucionalidade das leis entre o Judiciário e o Legislativo no exercício do poder reformador vai, no cenário brasileiro, muito além de um suposto monopólio da última palavra ao Supremo Tribunal Federal. Tais exemplos demonstram a forte capacidade de reação do Congresso Nacional às decisões da Corte, possibilitando resgatar para a arena política o debate de questões importantes de matriz constitucional. O caso da prática da vaquejada, considerada ofensiva aos valores e à norma expressa da Constituição pelo STF, é um exemplo disso: a lei estadual autorizou, a Suprema Corte vedou, o debate sobre o tema foi reacendido, a consulta pública do Senado apontou para um fortíssimo respaldo da população ao entendimento consolidado pela Corte e, para a surpresa de todos, em um curtíssimo espaço de tempo os representantes do povo apresentam e aprovam Proposta de Emenda à Constituição dispondo exatamente o contrário.

\section{CONCLUSÕES}

A investigação levada a efeito neste artigo permite indicar as seguintes conclusões, extraídas de cada um dos tópicos precedentes:

1. Para superar as dificuldades encontradas em modelos fortes de controle jurisdicional de constitucionalidade, apresentam-se como alternativa as teorias dos diálogos constitucionais, que visam a equilibram o caráter contramajoritário da atuação do Judiciário com a questão democrática. Apostam em um modelo de interação dialógica entre os tribunais e as instâncias de representação política, sem confiar a uma única instituição a prerrogativa de monopolizar a definição do significado da Constituição ou dar a última palavra sobre os temas constitucionais. Toma-se como base para a discussão a teoria dos diálogos institucionais desenvolvida no Canadá, inicialmente a partir do pensamento de Peter Hogg e Allison Bushell, os quais reconhecem nas reações do Legislativo às decisões de inconstitucionalidade do Judiciário - tais como superação normativa e modificação da legislação - uma forma de oxigenar democraticamente o sistema de judicial review. Analisa-se também a construção de Kent Roach, que identifica na seção 1 ("limitation clause") e na seção 33 ("override clause") da Constituição canadense formas legítimas de diálogo entre Cortes e Parlamento.

2. A teoria dos diálogos institucionais é também objeto de crítica por autores como Luc Tremblay, segundo o qual existem dois tipos de diálogos: (i) diálogo como conversa; (ii) diálogo como deliberação. Enquanto o primeiro é mais espontâneo e não se destina a um propósito específico de tomada de decisão, limitando-se a uma troca de ideias sem compromisso, sem caráter argumentativo ou de convencimento e sem a imposição de condições para sua validade, o segundo é mais formal e tem o propósito de alcançar um consenso, decidir qual é a melhor ação a ser tomada, e exige 
o cumprimento de diversas exigências, tais como o reconhecimento do interlocutor como igual falante, a existência de um processo racional de persuasão e uma troca de argumentos a serem considerados pelos participantes do debate. Somente o segundo tipo é capaz de conferir legitimidade às decisões tomadas com base nesse processo dialógico-deliberativo. Contudo, as interações existentes entre tribunais e órgãos legislativos se enquadram na modalidade de diálogo como conversa, por não cumprirem os requisitos do diálogo como deliberação, fato que tornaria meramente retórica a teoria dos diálogos constitucionais.

3. Nos sistemas constitucionais em que não há mecanismos específicos para o desenvolvimento de um diálogo institucional entre Legislativo e Judiciário a respeito do sentido da Constituição, nos moldes do Direito canadense, a saída para a concentração de poderes nas mãos dos tribunais se encontra na superação da posição jurisprudencial por parte do Legislativo ainda que sem previsão normativa expressa para tanto. Isso poderá ocorrer por meio da reedição de lei já declarada inconstitucional pelos tribunais ou pela aprovação de emenda à Constituição destinada a superar o entendimento judicial. O recorte metodológico do estudo limitou o objeto de análise à segunda situação.

4. Nos Estados Unidos, houve quatro oportunidades em que a Constituição sofreu emendas como forma de superar precedentes da Suprema Corte. No Brasil, a estratégia já foi usada com maior frequência. Foram selecionadas cinco situações para análise, nas quais o Congresso Nacional aprovou emendas à Constituição como uma nítida "resposta na sua cara" ("in your face reply") com o escopo de superar a decisão do Supremo Tribunal Federal: (a) Taxas de iluminação pública municipais - RE n.233.332 eECn. 39/2002; (b) Fixação do número de vereadores das Câmaras Municipais - RE n. 197.917 e EC n. 58/2009; (c) Teto remuneratório dos servidores públicos - ADI n. 14 e EC n. 19/1998 e MS n. 24.875 e EC n. 41/2003; (d) Progressividade do Imposto Predial e Territorial Urbano (IPTU) - RE n. 153.771 e EC n. 29/2000; (e) Prática da vaquejada - ADI n. 4.983 e EC n. 96/2017.

5. A análise das reações do Congresso Nacional às decisões do STF por meio de emendas à Constituição foi feita a partir das três perspectivas a respeito dos diálogos constitucionais anteriormente estudadas. Em primeiro lugar, examinou-se o tema sob o prisma da teorização de Hogg e Bushell. Com base da ideia dos autores de que haverá diálogos sempre que uma decisão de inconstitucionalidade tiver sofrido uma reação do Legislativo, na qual os valores constitucionais identificados pelo Judiciário tenham sido respeitados, constatou-se que na maior parte dos casos o Congresso Nacional simplesmente ignorou a argumentação do STF para superar o seu entendimento, salvo no caso das taxas de iluminação pública municipais. Em segundo lugar, sob o ponto de vista de Kent Roach, não se poderia admitir nenhuma das reações do Legislativo brasileiro às decisões do Judiciário mediante aprovação de emendas constitucionais como 
forma de diálogo, já que o autor exclui expressamente do seu conceito as hipóteses em que a reação do Parlamento é marcada por uma afronta à decisão judicial ou pela necessidade de alteração da Constituição. Em terceiro lugar, pela visão de Luc Tremblay, as reações do Congresso Nacional se enquadrariam na modalidade de diálogo como conversa, e não de diálogo como deliberação, de modo que tal espécie dialógica e insuscetível de conferir legitimidade democrática ao processo.

6. A conclusão final a que se chegou foi a de que, na experiência brasileira de aprovação de emendas à Constituição para superar decisões de inconstitucionalidade do Supremo Tribunal Federal, a maior parte dos casos caracterizou-se muito mais como uma sobreposição de monólogos entre o Legislativo e o Judiciário, ou aquilo que Kent Roach chamou de "batalha de gritos", na qual um poder tenta fazer prevalecer a sua compreensão do sentido constitucional sem preocupar-se em levar em conta a perspectiva do outro. Contudo, não se pode deixar de reconhecer que essas reações possuem a virtude de ter reacendido o debate acerca de importantes questões constitucionais na agenda política nacional, levando as instâncias democráticas a rediscutirem os temas analisados pelo STF nos espaços de deliberação pública.

\section{REFERÊNCIAS}

AGUILAR CAVALLO, Gonzalo. Juiz constitucional e diálogo jurisdicional multinível: a experiência chilena. Revista de Investigações Constitucionais, Curitiba, vol. 6, n. 1, p. 61-89, jan./abr. 2019.

ANTONELLI, Leonardo Pietro. Correção legislativa da jurisprudência: uma análise das emendas constitucionais em matéria tributária. Rio de Janeiro: Editora JC, 2015.

ARAÚJO, Luiz Fernando Diniz. O ativismo judicial e constrangimentos a posteriori. Revista de Investigações Constitucionais, Curitiba, vol. 5, n. 1, p. 129-150, jan./abr. 2018.

AVILA, Ana Paula Oliveira; MELO, Karen Cristina Correa de. Separação de poderes e diálogos institucionais nos litígios envolvendo o direito à saúde. Revista de Investigações Constitucionais, Curitiba, vol. 5, n. 1, p. 83-108, jan./abr. 2018.

BARBOSA, Antonio Ezequiel Inácio; LIMA, Martonio Mont'alverne Barreto. Influência das teorias dos diálogos institucionais e da última palavra provisória no pensamento constitucional brasileiro contemporâneo. Revista de Investigações Constitucionais, Curitiba, vol. 5, n. 1, p. 109-128, jan./ abr. 2018.

BATEUP, Christine. The dialogic promise: assessing the normative potential of theories of constitutional dialogue. Brooklyn Law Review, New York, v. 71, n. 3, p. 1109-1180, 2006. p. 1109.

BLACKSTONE, Bethany. An analysis of policy-based congressional responses to the U.S. Supreme Court's constitutional decisions. Law \& Society Review, Salt Lake City, v. 47, n. 1, p. 199-228, 2013.

BRANDÃO, Rodrigo. Supremacia judicial versus diálogos constitucionais: a quem cabe a última palavra sobre o sentido da Constituição? Rio de Janeiro: Lumen Juris, 2012. 
BRASIL. Câmara dos Deputados. Exposição de motivos da EMC 41-2003. Disponível em: <http:// www2.camara.leg.br/legin/fed/emecon/2003/emendaconstitucional-41-19-dezembro-2003-497025-anexo-pl.pdf >. Acesso em 24 abr. 2020.

BRASIL. Câmara dos Deputados. Parecer do Relator Dep. Arnaldo Faria de Sá pela aprovação da PEC n.॰ 379, de 2009. Disponível em: <http://www.camara.gov.br/sileg/integras/684194.pdf>. Acesso em 24 abr. 2020.

BRASIL. Câmara dos Deputados. Parecer do Relator Dep. Custódio Mattos pela aprovação das PECs - 559/2002 e 504/2002. Disponível em: <http://www.camara.gov.br/proposicoesWeb/prop_ mostrarintegra? codteor $=85426 \&$ filename $=$ Tramitacao-PEC+559/2002>. Acesso em 24 abr. 2020.

BRASIL. Senado Federal. Consulta pública. Resultado apurado em 01.08.2017. Disponível em: <http://www25.senado.leg.br/web/atividade/materias/-/materia/127262>. Acesso em 24 abr. 2020.

BRASIL. Senado Federal. Parecer avulso do Relator Dep. Jefferson Peres. Disponível em: <http:// legis.senado.leg.br/sdleg-getter/documento?dm=4801236\&disposition=inline $>$. Acesso em 24 abr. 2020.

BRASIL. Senado Federal. Parecer da Comissão de Constituição, Justiça e Cidadania. PEC n 50, de 2016. Disponível em: <http://legis.senado.leg.br/sdleg-getter/documento?dm=4609589\&disposition=inline $>$. Acesso em 24 abr. 2020.

BRASIL. Senado Federal. Proposta de Emenda Constitucional n 50, de 2016. Disponível em: <https://legis.senado.leg.br/sdleg-getter/documento?dm=3035267\&disposition=inline $>$. Acesso em 24 abr. 2020.

BRASIL. Supremo Tribunal Federal. ADI n. 14. Rel. Min. Célio Borja. Tribunal Pleno. Julgado em 28/09/1989.

BRASIL. Supremo Tribunal Federal. ADI n. 5.105. Relator Min. Luiz Fux. Plenário. Julgamento em 01.10.2015.

BRASIL. Supremo Tribunal Federal. MS n. 24875. Rel. Min. Sepúlveda Pertence. Tribunal Pleno. Julgado em 11/05/2006.

BRASIL. Supremo Tribunal Federal. RE n. 153.771. Rel. Min. Moreira Alves. Tribunal Pleno. Julgado em 20/11/1996.

BRASIL. Supremo Tribunal Federal. RE n. 197.917. Rel. Min. Maurício Corrêa. Julgado em 24/03/2004.

CARVALHO FILHO, José dos Santos. Entre o guardião de promessas e o superego da sociedade: limites e possibilidades da jurisdição constitucional no Brasil. Revista de informação legislativa, v. 51, n. 202, p. 159-179, abr./jun. 2014.

CHRISTIANSEN, Matthew R.; ESKRIDGE JR., William N. Congressional overrides of Supreme Court statutory interpretation decisions, 1967-2011. Texas Law Review, Austin, v. 92, n. 6, p.1317-1541, 2014. 
CICHELERO, César Augusto; FERRI, Caroline; NUNES, Eduardo Brandão. From an idealized separation of powers to its practical problems in the Rule of Law. Revista de Investigações Constitucionais, Curitiba, vol. 5, n. 1, p. 15-40, jan./abr. 2018.

CUNHA, Carlos Renato; COSTA, Valterlei A. da;VALLE, Maurício Dalri Timm do. O sobrestamento legislativo de decisões do STF: diálogo constitucional e o papel do judiciário como ator com poder de veto no Brasil. A\&C - Revista de Direito Administrativo \& Constitucional, Belo Horizonte, ano 18, n. 74, p. 193-216, out./dez. 2018.

GARAPON, Antoine. O juiz e a democracia: o guardião de promessas. 2. ed. Rio de Janeiro: Revan, 2001.

HACHEM, Daniel Wunder; PETHECHUST, Eloi. Supremacia judicial no constitucionalismo brasileiro: riscos à democracia e as alternativas das teorias dos diálogos constitucionais. Revista Brasileira de Estudos Políticos, v. 121, p. 203-250, jul./dez. 2020.

HIRSCHL, Ran. Towards juristocracy: the origins and consequences of the new constitutionalism. Cambridge: Harvard University Press, 2004.

HOGG, Peter M.; THORNTON, Allison A. Bushell; WRIGHT, Wade K. Charter dialogue revisited: or "much ado about metaphors". The Osgoode Hall Law Journal, Toronto, v. 45, n. 1, p. 1-65, 2007.

HOGG, Peter W.; BUSHELL, Allison A. The Charter dialogue between courts and legislatures (or perhaps the Charter of Rights isn't such a bad thing after all). The Osgoode Hall Law Journal, Toronto, v. 35, n. 1, p. 75-124, 1997.

LEAL, Mônia Clarissa Hennig; MORAES, Maria Valetina de. "Diálogo" entre Poderes no Brasil? Da inconstitucionalidade da regulação da vaquejada à vaquejada como patrimônio cultural imaterial brasileiro: uma análise crítica. Revista de Investigações Constitucionais, Curitiba, vol. 5, n. 1, p. 63-81, jan./abr. 2018.

LECLAIR, Jean. Réflexions critiques au sujet de la métaphore du dialogue en droit constitutionnel canadien. Revue du Barreau, Montréal, v. 64, num. spécial, p. 377-420, 2003.

LIMA, Fernando Rister de Souza; VILLAS BÔAS FILHO, Orlando. Separação dos poderes e complexidade social - uma releitura sistêmica. Revista de Investigações Constitucionais, Curitiba, vol. 5, n. 1, p. 189-220, jan./abr. 2018.

LIMA, Flávia Danielle Santiago; GOMES NETO, José Mário Wanderley. Autocontenção à brasileira? Uma taxonomia dos argumentos jurídicos (e estratégias políticas?) explicativo(a)s do comportamento do STF nas relações com os poderes majoritários. Revista de Investigações Constitucionais, Curitiba, vol. 5, n. 1, p. 221-247, jan./abr. 2018.

LOPES FILHO, Juraci Mourão; CIDRÃO, Taís Vasconcelos. A (in)constitucionalidade da vaquejada: desacordos, integridade e backlash. Revista de Direito Econômico e Socioambiental, Curitiba, v. 9, n. 3, p. 119-160, set./dez. 2018.

MANEIRO, Renata de Marins Jaber. Mandado de injunção, diálogos constitucionais e o papel do STF. Curitiba: Juruá, 2016. 
MANEIRO, Renata de Marins Jaber; PULCINELLI, Eliana. Litígio estratégico, vinculação de precedentes e abertura ao diálogo constitucional na construção do provimento jurisdicional. Revista de Investigações Constitucionais, Curitiba, vol. 4, n. 2, p. 193-219, maio/ago. 2017.

MANFREDI, Christopher P.; KELLY, J. B. Six degrees of dialogue: A response to Hogg and Bushell. The Osgoode Hall Law Journal, Toronto, v. 37, n. 3, p. 513-527, 1999.

MARIANO, Cynara Monteiro; FURTADO, Emanuel Teófilo; ALBUQUERQUE, Felipe Braga; PEREIRA Fabrícia Helena Linhares Coelho da Silva. Diálogos Sanitários Interinstitucionais e a experiência de implantação do NAT-JUS. Revista de Investigações Constitucionais, Curitiba, vol. 5, n. 1, p. 169-188, jan./abr. 2018.

MENDES, Conrado Hübner. Direitos fundamentais, separação dos poderes e deliberação. 2008. 267 f. Tese de Doutorado em Ciência Política - Departamento de Ciência Política da Faculdade de Filosofia, Letras e Ciências Humanas, Universidade de São Paulo. São Paulo. 2008.

OLIVEIRA, Gustavo da Gama Vital de. Diálogo constitucional e correção legislativa da jurisprudência no direito tributário brasileiro. 2009. 252 f. Dissertação (Mestrado) - Universidade Estadual do Rio de Janeiro, Faculdade de Direito. Rio de Janeiro, 2009.

RESENDE, Augusto César Leite de; MOLINARO, Carlos Alberto. A interamericanização do direito administrativo sancionador brasileiro: reflexões sobre o princípio da tipicidade da infração disciplinar a partir do diálogo judicial internacional. A\&C - Revista de Direito Administrativo \& Constitucional, Belo Horizonte, ano 19, n. 76, p. 153-173, abr./jun. 2019.

$\mathrm{ROACH}$, Kent. Constitutional and Common Law dialogues between the Supreme Court and Canadian legislatures. Canadian Bar Review, Ottawa, v. 80, n. 1-2, p. 481-533, mar./jun. 2001.

SILVA, Cecília de Almeida; MOURA, Francisco; BERMAN, José Guilherme; VIEIRA, José Ribas; TAVARES, Rodrigo de Souza; VALLE, Vanice Regina Lírio do. Diálogos institucionais e ativismo. Curitiba: Juruá, 2010.

SILVA, Virgílio Afonso da. O STF e o controle de constitucionalidade: deliberação, diálogo e razão pública. Revista de Direito Administrativo, Rio de Janeiro, v. 250, p. 197-227, jan./abr. 2009.

TREMBLAY, Luc. The legitimacy of judicial review: the limits of dialogue between courts and legislatures. International Journal of Constitutional Law, Oxford, n. 4, v. 3, p. 617-648, 2005.

VICTOR, Sérgio Antônio Ferreira. Diálogo institucional, democracia e Estado de Direito: o debate entre o Supremo Tribunal Federal e o Congresso Nacional sobre a interpretação da Constituição. 2013. 200 f. Tese (Doutorado) - Universidade de São Paulo, Faculdade de Direito. São Paulo, 2013.

VIEIRA, José Ribas; EMERIQUE, Lilian Márcia Balmant; BARREIRA, Jônatas Henriques. Constitucionalismo popular: modelos e críticas. Revista de Investigações Constitucionais, Curitiba, vol. 5, n. 3. p. 277-302, set./dez. 2018. 